\title{
For One 'Storical' History of Arts Education: On the Many Stories of History
}

\author{
Marta Cabral \\ Universidade de Lisboa, Instituto de Educacao \\ Teachers College, Columbia University
}

\begin{abstract}
The assumption that there are as many histories as there are historians is present in this paper, addressing history(ies) of arts education and some representations of its purposes throughout the past two centuries [1].

Focusing on a topography [2] of arts education's goals as present in Portuguese literature, the proposed methodology uses fictional narratives to present some of the possible stories in a history of arts education, concerning different ways its existence in school curricula has been both advocated for and criticized.

Drawing from a particular set of Portuguese literature on the subject, this way of telling history establishes possible connections between the core group of educators examined and other international authors and thinkers in a rhyzomatic [3] way. This account of a history of arts education is anchored not in a geographical location or a time period, but in particular stories that such a history tells.
\end{abstract}

\section{Introduction}

This paper reflects a study set within a framework of both the History of Education and Art Education. In this diverse context, a transdiciplinary approach is used that deeply influences the study's methods and venture points.

This effort towards interdisciplinarity is set in the belief that the creation of knowledge may happen in fruitful ways within conversations across disciplines and fields of research. This belief in the advantages of interdisciplinarity has been stated by several authors in the dominant fields in this study, namely Sullivan [4] (in the field of art education) and Nóvoa [5] (in the field of history of education). "If an agreed goal of research is the creation of new knowledge," Sullivan argues, "then it should be agreed that this could be achieved by following different, yet complementary, ways" [4] and some of these ways might be nested in the exploration of methodologies and methods that may traditionally be linked to different disciplines. Nóvoa, also, argues for the need for efforts of disciplinary permeability, aiming for research strategies that create knowledge in this intersection that will likely be broader and different in nature than the knowledge one could create within one discipline alone [5]. This intersection is not a matter, however, of looking at the same issues through different lenses, 'reaching' more knowledge by using different sources to 'pursue' it. On the contrary, this interdisciplinarity represents an effort not to 'pursue' knowledge but to create it, in ways that would not exist otherwise, for this knowledge comes from the researcher's personal experiences with and within practices of inquiry coming from complementary fields.

The starting point of this research is set in the current climate of Portugal's educational panorama, where several curricular issues concerning arts education have been being discussed. Some of the most prominent aspects in this discussion are related to intrinsic notions and representations about arts education. Discussions are held about the roles the arts are thought to play in society and in education, about ways in which arts education is believed to currently exist, as it is believed to evolve in the future, and about ways in which it ought to be framed. Arguments about why the arts should or should not exist in school curricula and in educational systems in general have been in the order of the day, and numerous policies have been written on the subject. In this context, this study investigates aspects of an extended discussion that is read by the researcher in historical discourses about why and how arts education has been a part of educational curricula in the past two centuries, and it is upon such data that the researcher's analysis is created.

Educational discourses, statements and policies reflect the values of their times. In that understanding, it is important that when reading and analyzing these discourses we are aware that such values shift and change according to the contextspecific reigning 'normality' of a given time, or its "positive unconscious vision. [6]. Not only do we not always see the same values as important as those that have come before us, but we don't always see the same values at all, for "a period only lets some things be seen and not others. It 'illuminates' some things and so casts others in the shade" [6]. In any given 
time, we are often unaware of our own underlying value systems, as they mask themselves in what is considered 'the norm.'

In questioning what are generally considered to be some of the important priorities for arts education's policies and practices, current circumstances often give rise to 'the issues' under debate, dimming views and thoughts that are not generally considered as the most timely or relevant ones. With this in mind, the present study aims to contribute to the construction of understandings about how some ideas about arts education are valued and generally accepted in the Portuguese literature. In this effort, this research develops through the creation of a topography, one of the many possible topographies, [2] of some of the purposes that, according to the researcher's interpretation of current and past literature, have been attributed to the teaching of the arts in schools and their role in general education. Such a topography takes into consideration the inevitability of the existence and the presence of a myriad of many "dimmed" views, along with the impossibility of 'one definitive and single truth.'

A detailed view on a larger study, this article focuses mainly on specific aspects of the methodology suggested and used in this research. It begins by briefly introducing some of the methodological ideas in which the study is grounded, leading the way to the presentation of the research questions and of its design. After a presentation of the methodological tools used in the research process, the context in which the study evolves is defined. After the presentation of some preliminary findings, the article ends with a conclusion that reestates some of the research's characteristics as a subjective and personal endeavor, touching upon the importance of such characteristics.

\section{Methodology}

As any research study, there are underlying ideas and ways of seeing and thinking the world that shape and influence this research, and that are served by and serve the design, the questions, and the methodological tools used.

As stated in the previous section, this study exists within the belief of the impossibility of "pure objectivity' [7-9], and the acknowledgement that it presents knowledge created by the researcher, with all such personal subjectivities, experiences, and beliefs about the world.

As the researcher, the stories I see and I tell are the stories that $I$ see and $I$ tell, and that despite being based in thorough and consistent research are still nevertheless my own constructed interpretation of the data.

These beliefs shape this research in a "storical" [1] way, in which ideas are brought together in metaphors [10] that stand for the researcher's interpretations on the representations about the purposes attributed to arts education in the Portuguese literature in the period under study. The term storical is here used to explore the crafting of history in the creation of fictional narratives. These narratives, stories created by the researcher, are based on personal readings of the data gathered and created in the process of the research, and represent a way of working these data [1].

\subsection{Research Questions and Design}

Within this framework, the research is led by a main question: "What are the representations of the purposes attributed to arts education present in Portuguese literature from the early-nineteenth to the late-twentieth century? How are these informed by representations in the foreign literature as referenced by Portuguese thinkers? And what has been the lasting legacy of such representations?" [1].

From this main line of investigation other questions are created, relating these historical ideas to what may be read as current representations about arts education, its functions, and its presence in education. In order to create meaning and knowledge on these issues, this research is designed in a way that aims to organize data according to the stories that $I$ as the researcher read in the data, creating new series of connections between discourses that allow for the reading and construction of new stories. Each of the representations read in various discourses is grouped in places [2] of ideas, into realms of discourses in which the researcher brings to light enough commonalities between them to cluster them together forming a specific story about the purposes of arts education. These stories are hence some of the many stories that could be brought into existence in the interrogation of these issues, and have no pretention of being neither 'the' nor even ' $a$ ' definitive reading of the data created.

This study is set neither in Portugal alone, nor in a narrow time frame; it is not anchored in specific events contextualized in specific time periods, and it has no intention of establishing a 'definitive' arts education history. Instead, it tells one of the many possible stories that may be read in the written history of arts education; it tells a story created by its storyteller, a story that is composed of many stories. It is a story that is threefold and takes place throughout history and geography bound together by the constructions of the researcher. As all stories, the ones told here do not pretend to embrace every detail, to attend to every point of view, or to acknowledge every reality. They represent the standpoint, the context, and the individuality of the researcher, in a particular point in time.

In this sense, the stories in this research are a recognition of the contingencies of research and the welcoming of personal subjective biases that happen 
in any and every act of research, since "authors exercise consequential agency and intentionality in creating texts" [11]. These stories exist in a respect for the inexistence of 'pure and unbiased objectiveness,' and of 'one true' history of arts education and the discussions and rationales around it. [7].

This tale is about the purposes and goals of arts education as read by the researcher in historical discourses, which have reflected many of the representations expressed by educators about the various roles that the arts play, as well as some of the reasons used to justify their presence and their importance in general education. At question here are some of the different rationales used for arts education and its presence in school curricula and in the education of people in general, and discussions on why these arguments are important in the construction of current generally accepted views on the purposes of arts education. Have these purposes and rationales been the same throughout time? Can it be argued that arts education indeed does play the roles voiced in the literature? A literature review presents numerous writings about crucial roles arts education is argued to play in current-day education for varied reasons. Some justifications focus on, for example, holistic benefits; on benefits for brain development; in the nurturing of creativity; on improvement of cognitive skills and academic performance; on the encouragement of personal expression; or as a platform for social integration and respect for differences. But is the acknowledgment and the intentional pointing out of these purposes specific to contemporary contexts? Furthermore, where do these current arguments come from, and under what discussions did they originate in the Portuguese literature?

Aiming to suggest possible answers for these questions, this study uses historical discourses as sources and methodological tools coming from practices of inquiry from the fields of arts education and history of education. These discourses are writings and documents from the Portuguese literature in the period under study, and through which I read history as history reaches us. In those discourses, I read each author's representations about the purposes of arts education, and in those readings I base my interpretations about the questions being asked, the decisions being made, and the things that appear to be seen. To find, organize and to think about and through these discourses, different methodological strategies are used as tools, as the instruments I use to make my thinking process and my research happen.

\subsection{Methodological tools}

Within the methodological frame of this research, methodological tools are used in the process of collecting, analyzing, and creating data. With the methodological approach, these tools determine which data are regarded and which remain unattended and unconstructed in each study, for they guide the researcher's process.

Foucault's genealogy and archaeology [12] are some of the tools here mobilized, used as the primary set of tools of my methodology. These concepts are here used as a "domain of research," [12] in an effort of "defamiliari[zing] what is familiar" [13] and creating new stories through the re-reading and reinterpreting in the process of constructing data.

Genealogy, as defined by Foucault himself, "means that I begin my analysis from a question posed in the present" [14]. A question that in this case is rooted in generally accepted truths about the purposes attributed to arts education. Inquiring in what ways the present is different from the past [15], taken-for-granted assumptions about current values are shaken, and may be re-examined, re-interpreted and re-constructed by the researcher, and "legitimately reformed" [16] in different and new ways. As a method of analysis, genealogy deals with contingencies in the construction of possible outcomes of series of events rather than with the explanation of the 'causes' of the present. As Tamboukou argues, genealogy "searches in the maze of dispersed events to trace discontinuities, recurrences and play where traditional historiography sees continuous development, progress and seriousness" [17].

Archaeology, on the other hand, regards history throughout a "set of spatial and temporal coordinates" [18] and is more concerned with the past itself. In this way, genealogy reaches archaeology to the present, acting as its "strategic development" [19].

By way of genealogy and archaeology, the data is explored through discourse analysis [16]. The analysis of discourse asks how specific statements came to be, acknowledging the role of contingency in that process and recognizing that many other statements could have been brought to the fore instead [20]. In this reading and analysis of data, images are created in the representations about the purposes of arts education read in the discourses analyzed, brought to the fore by connections established between the ideas expressed by each author, emphasizing their similarities and differences, their points of agreement and of rupture, through time and geography.

In this research, such conceptual images about the goals and aims of arts education are, once identified, then linked to each other in new ways, forming clusters of ideas, each of them suggesting a different way of conceptualizing these purposes that are expressed by metaphors.

By using the term metaphor, I take Davidson's [10] interpretation of it, as something that "doesn't 
say anything beyond its literal meaning," but nevertheless "does lead us to notice what [we] might not otherwise have noticed" and may "bring surprising analogies and similarities to our attention [providing] a kind of lens or lattice, as Black says, through which we view the relevant phenomena." Metaphor here, not relying on sets of commonknowledge assumptions about the meaning of words, relies instead on its most literal reading, while still recognizing and welcoming personal interpretation and individual assumptions from each reader. Metaphor means what it literally means - being naturally different, personal and subjective for every person who reads it.

Inside the realm of metaphors, this research's data is worked and understood through narrative [11], facing the researcher not only as a tool in data collection, but as a constructor of the knowledge itself, acknowledging that all research is personal, subjective, and based on the researcher's interpretations [21].

Narrative is here seen as a form of inquiry: its function is not to 'illustrate' the data or simply provide another form of representation, but it is a way to think data differently, allowing for the making of meaning and the creation of knowledge [11]. Narrative inquiry brings to the fore not only different ways of relating to data, but different data in themselves - detailed, specific, and even sensorial data, which engages both researcher and reader on a personal level, promoting relationships between authors and readers different than the ones other kinds of research would [22]. In this way, the goal of narrative research is not as much its verisimilitude as it is the feeling of belief it may evoke in its reader $[11,22,23]$.

In the data-based fictional stories told for each of the study's metaphors, the researcher-author is freed from the supposed and inauthentic neutrality and impartiality often present in traditional science and history, and may hence give an account of history that, not being any more personal than any other, is so in an open and assumed way.

\subsection{Definition of context}

Although within a broad frame of data gathering and creating, some specific criteria were necessarily set to guide and give boundaries to the process. These criteria concern both time and geographical framework; such boundaries, although not impermeable and inflexible, provide structure to the study.

To direct the search in the Portuguese literature, a set of pedagogues/educators was selected according to the significance and relevance of their writings published during the period under research (from the mid-nineteenth to the end of the twentieth century) and thoroughly studied. From the reading of accounts and thoughts on and about arts education and its importance, the researcher created connection that linked statements together in a way that is different than their original organization: instead of being primarily organized by author, these statements are organized according to the metaphors read in them and articulated by the researcher.

From this reading of Portuguese educators, the researcher also established connections to international discourses by the citations and references made in the analyzed statements, linking the thoughts of the initially selected authors to the thoughts of their international peers, integrating the stories in an international context of ideas.

Although those representations on the purposes of arts education as read in the analyzed statements by the selected Portuguese educators are the basis for the tale I am writing, they are not the story itself. This story begins with the creative work of constructing the possible metaphors and some of the narrative stories such metaphors may have to tell us, out of which are born conceptual images of the purposes attributed to arts education. Such conceptual images that are articulated in the narrative stories of each metaphor allow us to step back, reframe and re-examine purposes attributed to arts education that we are already familiar with, but to see them in a new light, to examine them anew." A broad time frame, set in a period when arts education was vastly discussed and questioned, provides sufficient scope to cover different perspectives, discourses and lenses. During this time, arts education walked a long and not always smooth path. It has been discussed and modified, advocated for and against, exalted and condemned under the most diverse arguments.

Although it may be argued that arts education has, along with art itself, a history (or histories...) reaching far back, arts education as a discipline was introduced in European and North American schools as a subject of study in general education during the second half of the nineteenth century, when modern disciplines were being introduced in school systems taking the place of the classical curriculum [24]. Amid the twentieth century, discussions about arts education worldwide were pushed even further and arguments for and against its function and importance (or unimportance) flourished.

In this context, the geographical setting of this research is also quite broad, although bounded by the initially selected educators and the educators they cite in their writings. According to Meyer and Kamens [25], world currents are determinant in defining national curricula - most core decisions in national education systems, they argue, are defined at an international level, through currents of thought and hegemonic values that are eventually assimilated as components of national ideologies. Pedagogical ideas travel wide and well, and pedagogues and 
educators are influenced by each other's ideas in a worldwide community of discourse. Being so, it makes sense to look at these discourses in a broad perspective that does not ignore this global dimension, but instead welcomes it and uses it for its own purposes.

These theoretical frameworks and methodological constructions allow the researcher to look at the history of arts education as told in the source authors' writings in a way that problematizes a series of questions as expressed in the research questions that guide this study. Instead of focusing on a period or place and creating stories according to that, I address a specific problem as the set for my analysis. This research is set within the broad boundaries of the history of ideas, understood as a "style of analyses, a putting into perspective" [16].

This approach is set in what Foucault calls general history, "eschewing the 'totalizing' theme" [6]. Under this umbrella, the issues that arise are addressed in a "storical" context: contrary to explaining each metaphor according to a single social and historical context, I concentrate on contextualizing them within the tale I'm constructing, using their own places of ideas as thinking frameworks. These stories justify and complement one another in ways that make them part of a larger narrative that is built upon them.

\section{Preliminary Findings and Discussion}

In this framework, the stories that compose this study are created with the methodological tools, within the temporal and geographical contexts described, and under the assumptions exposed. The preliminary findings of this research are presented in the following three metaphors, that of Salvation, that of Language, and that of Ownership.

The first presented of these stories and metaphorical images is based on the idea of arts education as Salvation [1]. In this metaphor, arts education is seen as one that saves from evils of diverse sources: salvation from social dangers, such as poverty or exclusion; from immorality and inappropriate activities; or from the constraints of art education itself. This idea has been present in discourses coming from many different times and locations, and even the arguments for the inclusion of arts education as a discipline in modern curricula might be thought of in the realm of a salvific metaphor, namely within moral and social development.

By the mid-nineteenth century, the nation-state as such was being established in the Western world, and public mass school system was defining itself along with the nation-state. Modernity demanded the construction of citizens, and girls and boys were to become productive and educated citizens to their nations. School systems were the tools and the stage for that alchemy, helping to "[ensure] the appropriate control of citizenry" [26] needed. In this context, art was a privileged means to construct the national culture that would hold the state and the citizens as part of it. Contributing to that, arts education held its place in the new discipline-based curriculum [26]. In this conjuncture, arts education may be seen as fulfilling a salvific role not only to individual students and their personal and social perils and dangers such as the above described, but also rescuing the nation itself, by making each child an appropriate and fit part of the greater whole that was defined by the supervision of its individuals.

The second cluster of ideas sees art as a Language, and arts education as a means for fluency in it [1]. In this metaphor, the role of arts education is to allow students to 'be and think artistically,' similar to how other school subjects might promote thinking in discipline-bound ways such as, for example, thinking mathematically or historically. In this story of language are metaphors related to expression and communication, in which art serves the purpose of a language "through which children [can] lift their ideas above the commonplace level to express them meaningfully" [27]. Also relevant in this story of language are ideas related to the importance of art for its own sake. One example of this concern may be seen in the 1955 International Conference on Public Education's recommendation to ministries of education worldwide. In this address, it is argued that because "art is a valuable means of education in itself [... it] should be taught in all primary schools, and it should be regarded as equal in importance to other subjects of instruction [25].

Out of the discussion of these clusters of ideas, a third metaphor is created by the researcher, arguing arts education instead as a way of Ownership [1]. Contrary to the previous two metaphors that arose directly out of a reading of the source authors' thoughts and ideas, this third metaphor is constructed in the discussion of those readings, and in the process of questioning Salvation and Language along with current literature. The metaphor of Ownership is, hence, gesturing towards yet another conception and another reading about arts education and its place in education, one that sets the stage for a shift in the role of the student.

Although this idea is strongly connected to the metaphor of Salvation, since in both metaphors the goal is for 'a better life and a better world,' they differ in the way they present it. In the idea of salvation, 'better life' means 'better people,' better prepared, skilled, globally and healthy developed. In the realm of empowerment as understood as ownership, it is the individual's role that is in itself shifted - from learner to participant, from consumer to creator, from recipient to author.

In this metaphor of Ownership, arts education is re-created and perceived by students and teachers as 
a tool for empowerment, transforming the viewer's role in the artistic experience, shifting it from a passive receiver to an active creator. This situation not only gives more control to the student/viewer over their own learning, allowing him or her the leap from the stillness of a passive observer to the task of an active creator, but it also defines art as in-between process and product. In shifting the notion of authorship, this notion of ownership settles the argument fought for either process or product as the 'true center' of art and arts education, setting the student instead in that central position [28].

In this view of Ownership, arts education is what gives every student the consciousness of his or her own creative self, creating a new image of the self as an art practitioner "who elect[s] to remake art within and as the audience" [29]. As a viewer and as an active thinker, each student may exercise his or her role as a critic by seeing, suggesting, interacting and creating works of art. The student's role as a critic is no longer to interpret and uncover a hidden meaning, that is somehow underlying in the work of art. Rather, the role of the student is to create a new meaning - to create knowledge in and through his or her interaction with the artworks. By filling in the conceptual gaps left open in the work [30], student/artist viewers become also responsible for the construction of artworks and their meaning, owning their own role as creators in their own right. In this way, arts education becomes a path for authorship and ownership, helping students to empower themselves.

\section{Conclusion}

The metaphors and stories created in this study become a lens through which to look at discourses and practices in a critical way that sets the stage for a deep and informed reflection on the purposes we attribute to arts education, purposes that we are often already familiar with, but that need to be continually examine anew.

These stories and metaphors are the product of my own subjectivities and biases as the researcher, and have no pretention of establishing a 'single and definitive' history of arts education and its purposes for the period under study. These metaphorical stories do not stand for set images with fixed meanings that represent 'realities' but, on the contrary, they stand for one of the many possible sets of ideas about a specific subject, filled with subjectivities and personal meaning.

These places of metaphors or conceptual images are not impermeable and bounded compartments, but interconnected places of ideas. They are parts of a rhizome [2], and so can be expected to continue to grow and develop in new and unexpected ways, leading to paths of new stories about the purposes of arts education in our educational systems, theories and understandings.

The importance of this research stands strongly in the establishing of a personal relationship with history of arts education, one that brings forth questioning, ownership, and a deep sense of possibility. Being aware of the role of contingency in the construction of history(ies) brings with it an awareness of personal responsibility, humility and possibility that leads to a questioning of taken for granted assumptions. The awareness of the impossibility of one single unbiased and objective truth allows for the unpacking of previously unquestioned statements, shifting researcher and reader to the role of constructors of history(ies).

\section{References}

[1] Cabral, M. A Genealogy of Our Convictions: Salvation and Language in one 'Storical' History of Arts Education. Universidade de Lisboa Instituto de Educação, Lisboa, (Unpublished paper) 2012.

[2] Malpas, J. Heidegger's topology : being, place, world. MIT Press, Cambridge, Mass., 2006.

[3] Deleuze, G., Guattari, F. and ebrary Inc. A thousand plateaus capitalism and schizophrenia. University of Minnesota Press, City, 1987.

[4] Sullivan, G. Research Acts in Art Practice. Studies in Art Education. A Journal of Issues and Research, 48, 1 2006), 19-35.

[5] Nóvoa, A. S. d. Perspectivas de renovação da história da educação em Portugal. FPCE, City, 1993.

[6] Rajchman, J. Philosophical events : essays of the '80's. Columbia University Press, New York, 1991.

[7] Luker, K. Salsa dancing into the social sciences : research in an age of info-glut. Harvard University Press, Cambridge, Mass., 2008.

[8] Van Maanen, J. Tales of the field : on writing ethnography. University of Chicago Press, Chicago, 2011.

[9] Richardson, L. Writing: A Method of Inquiry. Sage, City, 2000.

[10] Davidson, D. What Metaphors Mean. Critical Inquiry, 5, 1 1978), 31-47.

[11] Banks, S. Writing as Theory. In Defense of Fiction. Sage, City, 2008. 
[12] Foucault, M. The Order of Things. New Press, City, 1997.

[13] Harootunian, H. D. Foucault, Genealogy, History. The Pursuit of Otherness. Rutgers University Press, City, 1988.

[14] Foucault, M. and Kritzman, L. D. Politics, philosophy, culture : interviews and other writings, 1977-1984. Routledge, New York, 1990.

[15] Foucault, M. and Rabinow, P. The Foucault reader. Pantheon Books, New York, 1984.

[16] Foucault, M. The archaeology of knowledge; and The discourse on language. Pantheon Books, New York, 1982.

[17] Tamboukou, M. Women, Education and the Self. A Foucauldian Perspective. Palgrave Macmillan, Hampshire and New York 2003.

[18] Dean, M. Critical and effective histories : Foucault's methods and historical sociology. Routledge, London ; New York, 1994.

[19] Kendall, G. and Wickham, G. Using Foucault's methods. Sage Publications, London; Thousand Oaks, Calif., 1999.

[20] Foucalt, M. On the Archaeology of the Sciences. New Press, City, 1997.

[21] Miller, J. L. Sounds of silence breaking: Women, autobiography, curricilum. Peter Lang Publishing, New York, NY, 2005.

[22] Ellis, C. and Bochner, A. P. Autoethnography, personal narrative, reflexivity. Sage Publications, City, 2000.

[23] Coles, R. and NetLibrary Inc. The call of stories teaching and the moral imagination. Houghton Mifflin, City, 1989.

[24] Kamens, D. and Cha, Y.-K. The Formation of New Subjects in Mass Schooling: Nineteeth Century Origines and Twentieth Century Diffusion of Art and Physical Education. The Falmer Press, City, 1992.

[25] Meyer, J. and Kamens, D. Conclusion: Accounting for a World Curriculum. The Falmer Press, City, 1992.

[26] Popkewitz, T. S. and NetLibrary Inc. Struggling for the soul the politics of schooling and the construction of the teacher. Teachers College Press, City, 1998.
[27] Barkan, M. A Foundation for Art Education. The Ronald Press Company, New York, 1955.

[28] Baldacchino, J. The Praxis of Art's Deschooled Practice. International Journal of Art \& Design Education 27.3 (2008) 27.3 (2008 2008), 241-348.

[29] Baldacchino, J. Hope in groundlessness: Art's denial as pedagogy. Journal of Maltese Educational Research, 3, 1 2005), 1-13.

[30] Hubard, O. The Act of Looking: Wolfgang Iser's Literary Theory and Meaning Making in the Visual Arts. International Journal of Art \& Design Education, 27, 2 2008), 168-180. 